\title{
Lilla Moroz-Grzelak
}

\section{Macedońska pamięć historyczna. Imaginarium pomnikowe}

Pamięć o przeszłości pozostaje istotnym elementem scalającym wspólnotę państwowa, przypominając o jej wartości i miejscu w świecie. W tym celu państwa i narody często wykorzystują stare mity, które odnoszą się do ich dziejów i wskazują na własną rangę w obliczu realnego bądź wyimaginowanego zagrożenia. Poprzez mityzowanie przeszłości następuje wzmacnianie tożsamości wspólnoty i potwierdza się jej znaczenie ${ }^{1}$. W tym celu podkreśla się wartość własnej historii i bohaterów, którzy w przeszłości byli związani z daną przestrzenią. Myślenie takie opiera się na założeniu, że niezależnie od stanu faktycznego przybywający na dane terytorium przyjmują zasadę primordialności jako własnego prawa historycznego do zajmowanych ziem. W takiej sytuacji tworzone czy wykorzystywane stare mity nakierowane są na komunikację wewnątrz grupy, nie zaś na komunikację międzygrupową. Jak zauważa macedońska historyk Nade Proeva w odniesieniu do własnego narodu, także pamięć historyczna w jej kraju oparła się na wykorzystaniu mitów z przeszłości, te zaś, choć stwarzaja pozory wiedzy, podlegają politycznej manipulacji ${ }^{2}$. Duchowa więź Słowian macedońskich z zamieszkiwanym terytorium jako sferą własnych przodków sprawiła, że do rodzimej tradycji asymilowano postacie antyku i średniowiecza, podkreślając ich związki w przeszłości z tą przestrzenią i konstruując w ten sposób własny panteon narodowy ${ }^{3}$. W tym kontekście kwestią drugorzędną pozostaje fakt, że włączono don postacie, które znalazły swe miejsce także w bułgarskiej, serbskiej czy greckiej spuściźnie kulturowej.

${ }^{1}$ E. Cassirer, Mit państwa, Warszawa 2006, s. 29.

${ }^{2}$ N. Proeva, Savremeni makedonski mit kao odgovor na nacionalne mitove suseda: albanski panilirizam, bugarski pantrakizam i grčki panhelenizam, „Zgodovinski časopis” 2010, br. 1-2, s. 179.

${ }^{3}$ A. Naumow, Wspótczesna rekonstrukcja macedońskiego procesu historycznego i literackiego, [w:] Przemiany w świadomości i kulturze duchowej narodów Jugosławii po roku 1991, red. J. Kornhauser, Kraków 1999, s. 57-69; L. Moroz-Grzelak, Macedońskie dziedzictwo cyrylometodejskie, „Slavia Meridionalis” 2008, nr 8, s. 327-341. 
8 września 2011 r. w Republice Macedonii pod hasłem „Zaedno pod edno sonce" (,Razem pod jednym słońcem”) uroczyście obchodzono 20-lecie niepodległości państwa. Była to „okragła” rocznica związana z wydarzeniami sprzed dwóch dekad, kiedy w następstwie rozpadu Jugosławii, kilka miesięcy po wystapieniu Chorwacji i Słowenii ze struktur federacji, w Macedonii przeprowadzono referendum niepodległościowe. W głosowaniu udział wzięło 71\% uprawnionych obywateli, gdyż większość ludności albańskiej wybór zbojkotowała; 95\% uczestników opowiedziało się za suwerennością i Macedonia bez rozlewu krwi zyskała niezawisłość. Uwzględniając wyniki referendum, dnia 17 września 1991 r. proklamowano niepodległość państwa. Powrócono wówczas do wielkich postaci z historii przestrzeni macedońskiej, odwołując się nie tylko do św. Cyryla i Metodego i cara Samoila, jako bohaterów własnego dziedzictwa kulturowego, ale także do Aleksandra Wielkiego czy Justyniana Wielkiego, czyniąc z nich filary własnej państwowości i pieczętując w ten sposób ich trwałe miejsce we własnej tradycji historycznej.

I choć preambuła do konstytucji Republiki Macedonii ${ }^{4}$ odwołuje się do historycznego, kulturalnego, duchowego i państwowego dziedzictwa narodu macedońskiego oraz jego trwającej wieki walki o wolność narodową i społeczna, o zbudowanie własnego państwa, to w zdeklarowany sposób nawiązuje do wydarzeń z historii XX w. Faktami najwyższej rangi, przywoływanymi we wstępie, sa: powstanie ilindeńskie, które wybuchło 2 sierpnia 1903 r.; istniejąca w trakcie tego zrywu antytureckiego przez dziesięć dni Republika Kruszewska; uchwały Antyfaszystowskiej Rady Wyzwolenia Narodowego Macedonii (Antifašističko Sobranie za Narodno Osloboduvanje na Makedonija, ASNOM) z 2 sierpnia 1944 r.; ciagłość państwa macedońskiego w ramach federacyjnej Jugosławii; a także referendum z 8 września $1991 \mathrm{rr}^{5} \mathrm{~W}$ tym niewielkim kraju, który obejmuje powierzchnię tzw. Macedonii Wardarskiej, zajmuje powierzchnię $25713 \mathrm{~km}^{2} \mathrm{i}$ liczy niewiele ponad $2 \mathrm{mln}$ ludzi, pamięć o przeszłości zajęła miejsce szczególne. Do dziedzictwa państwa przyjęto postacie z tych okresów przeszłości ziem macedońskich, o których konstytucja nie wspomina, ale prawie wszystkie zaistniały jako własne w okresie budzenia się macedońskiej tożsamości jeszcze w XIX stuleciu.

Najważniejszym bohaterem współczesnej macedońskiej historii stał się Aleksander Wielki (IV-III w. p.n.e.). Odwoływanie się do antycznego władcy i twórcy rozległego imperium ma w Macedonii swoją długą tradycję. W XIX w.

${ }^{4}$ Nie posługuję się terminem FYROM (Former Yugoslav Republic of Macedonia) Była Jugosłowiańska Republika Macedonii, za którą w instytucjach międzynarodowych opowiadają się Grecy.

${ }^{5}$ Konstytucja Macedonii, wstęp J. Jackowicz, Warszawa 1999, s. 19.

${ }^{6}$ Po wojnach bałkańskich, na mocy postanowień traktatu w Bukareszcie z 10 lutego 1913 r. terytorium Macedonii podzielono pomiędzy Grecję (51,57\% - Macedonia Egejska), Bułgarię (10,11\% - Macedonia Piryńska) i Serbię (38,32\% - Macedonia Wardarska). Zob. m.in.: I. Stawowy-Kawka, Historia Macedonii, Wrocław 2000, s. 169-171. 
stał się on dla prawosławnych Słowian tych ziem „,silnym argumentem” w staraniach o niezależność, dowodząc istnienia własnej tożsamości w obliczu państwowej dominacji Imperium Osmańskiego oraz supremacji Greków w Cerkwi. Wtedy też zyskał jednoznaczny identyfikator terytorialny, który wskazywał na miejsce jego pochodzenia - Aleksander Macedoński. Wówczas, wzorem XVI-wiecznego autora chorwackiego Vinko Pribojevicia i XVIII-wiecznego poety Andrii Kačicia Miošicia, uczyniono z Aleksandra słowiańskiego władcę, nadając mu cechy wojownika walczącego o wolność chrześcijan, którzy pozostawali pod osmańskim panowaniem i greckim zwierzchnictwem w Cerkwi ${ }^{7}$. Orędownicy macedońskiej niezależności werbalizowanej $\mathrm{w}$ piśmiennictwie tego okresu powoływali się na jego słowiańskość i przynależność do świata prawosławia. Miejscowa elita, wyrażając w ten sposób tożsamość terytorialna, demonstrowała poczucie swego udziału w słowiańskim i chrześcijańskim świecie, sakralizując zajmowany obszar i wskazując na ciagłość trwania etnosu. Choć u progu XX w. Aleksander Wielki stracił cechy bohatera słowiańskiego i prawosławnego, to z Macedonia związał go trwale topos ziemi - wspólnoty miejsca z ludnością zamieszkują te same tereny. Powoływano się na niego nie tylko w wierszach, ale także w dokumentach politycznych, które odzwierciedlają późniejsze starania macedońskich bojowników o własną niepodległość. Jego mit, jako bohatera macedońskiego, wyciszony w okresie istnienia republiki w ramach federacji jugosłowiańskiej, powrócił w samodzielnej Macedonii, dokumentując jego związki z tym właśnie państwem. W przeddzień uroczystych obchodów święta niepodległości otwarto pod Skopje nowoczesne lotnisko, które w wyniku sporów macedońsko-greckich o nazwę, pod wpływem mediacji tureckiego inwestora, wyjątkowo nazwano lotniskiem im. Aleksandra Wielkiego. Jednak już tablica na monumencie przedstawiającym antycznego króla na koniu w hali przylotów przywraca właściwe w tym kraju nazewnictwo - Aleksander Macedoński.

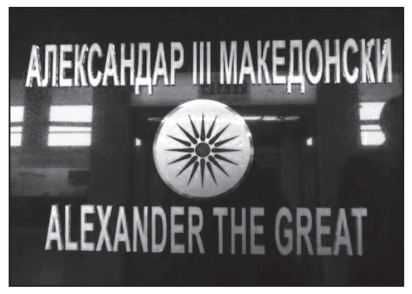

Zdjęcie 1. Tablica na pomniku stojącym na lotnisku Aleksandra Wielkiego ${ }^{8}$

7 Etapy ideologizacji postaci Aleksandra Wielkiego w przestrzeni bułgarsko-macedońskiej zostały ukazane w książce L. Moroz-Grzelak, Aleksander Wielki a macedońska idea narodowa. Stowiańskie losy postaci antycznej, Warszawa 2004.

8 Zdjęcia zamieszczone w tekście zostały wykonane przez autorkę tekstu w listopadzie $2011 \mathrm{r}$. 
Efektem rocznicowych obchodów święta republiki był kolejny pomnik antycznego bohatera, który odsłonięto na centralnym placu stolicy - Ploštad Makedonija. Prawie 30-metrowej wysokości pomnik-fontanna, pod oficjalną nazwa „Voijn na konj”, autorstwa młodej rzeźbiarki Valentiny Stefanovskiej, wpisuje się w ramy realizowanego projektu architektonicznego „Skopje 2014”. W swoim założeniu artystyczny koncept ma przywracać pamięć o przeszłości państwa i miasta poprzez odbudowanie, wiele lat po trzęsieniu ziemi z 1963 r., gmachów użyteczności publicznej oraz pomników wielkich postaci macedońskiej historii.

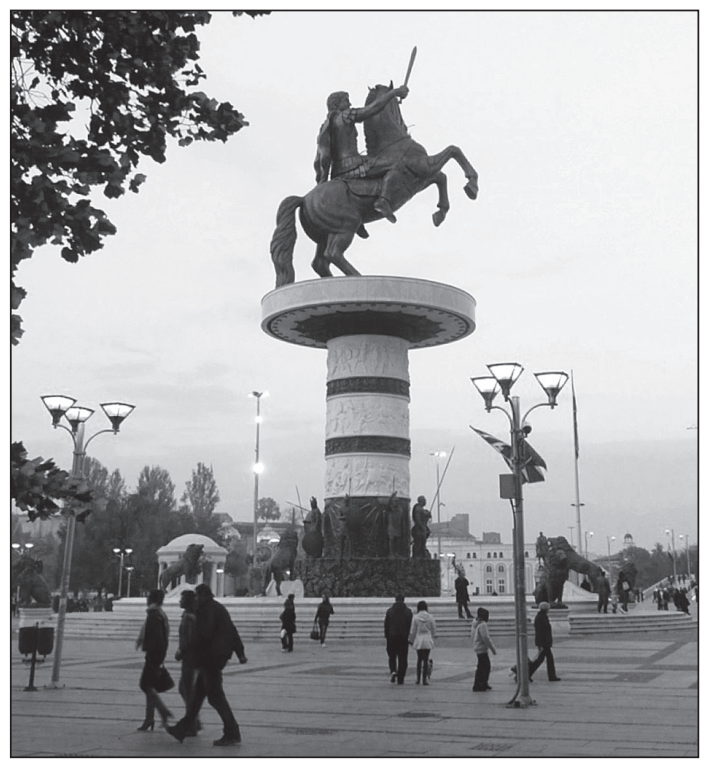

Zdjęcie 2. Pomnik-fontanna „Vojin na konj”, projekt: Valentina Stefanovska

Pomnik antycznego władcy staną w otoczeniu odsłanianych sukcesywnie innych monumentów przedstawiających bohaterów historycznych, którzy mieli związek z terytorium macedońskim, a współcześnie mają dowodzić więzi z dziedzictwem cywilizacyjnym Macedończyków. Za taką postać uznano też Justyniana Wielkiego (483-565), którego statua, projektu Rozy Pavleskiej, została odsłonięta 16 czerwca 2011 r. Jednak jego obecności w macedońskiej tradycji nie poświadcza XIX-wieczna twórczość ludowa czy piśmiennictwo autorów tego obszaru9. Impera-

9 Т. Вражиновски, Христијанските светии во нарадната традииија на Македониите, [w:] tenże, Македонска народна митологија. Народна традиција, религија, култура, Скопје 2002, s. 85-91. 
tor Wschodniego Cesarstwa Rzymskiego (527-565), uznawany za jednego z najwybitniejszych cesarzy bizantyńskich, twórca rozległego imperium, kodyfikator klasycznego prawa rzymskieg $0^{10}$ znalazł tu swoje miejsce ze względów wyznaniowych i przez kontakty z Ochrydem. W Kościele prawosławnym w związku z szerzeniem wiary został uznany za świętego, a w Macedonii dodatkowo przysłużył się do odbudowy zniszczonego w wyniku trzęsienia ziemi Ochrydu, w którym od IV w. ustanowiona była stolica biskupia prowincji Nowy Epir. Miasto zostało wzniesione ponownie w VI w. na rozkaz cesarza Justyniana i zyskało wówczas status metropolii kościelnej i stolicy prefektury Ilirii Iustiniana Prima.

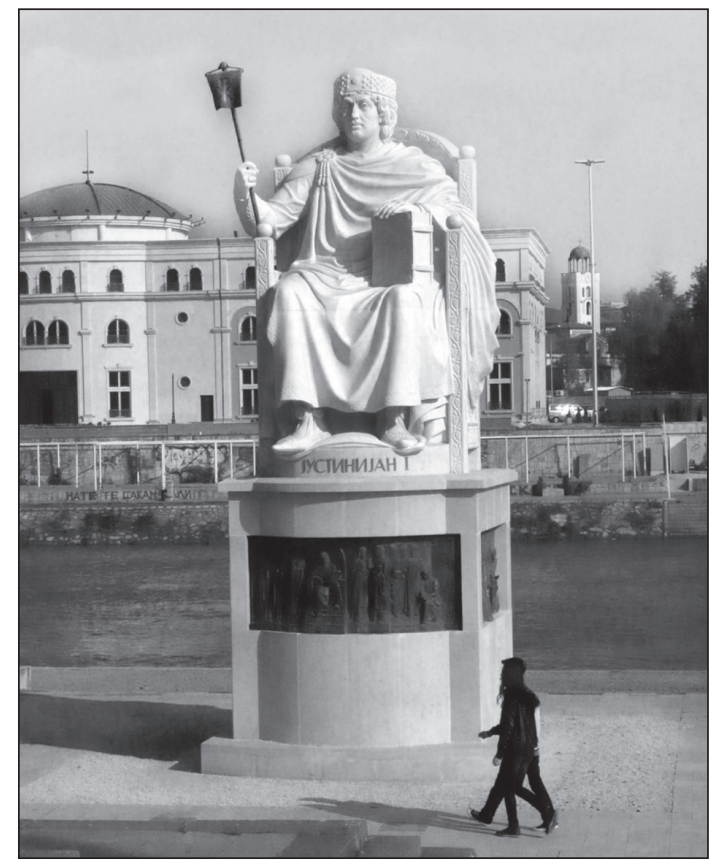

Zdjęcie 3. Pomnik Justyniana Wielkiego, projekt: Roza Pavleska

Umiejscowienie pomnika imperatora na Placu Macedonia miało więc swoje uzasadnienie. Wzmacniały je dodatkowo twierdzenia o słowiańskim pochodzeniu władcy, które pojawiły się jeszcze w XVII w. za sprawą Nikoli Alemanusa, kierującego biblioteką watykańska. Ze spisu Iustiniani vita, miał on

${ }^{10}$ A. Krawczuk, Justynian Wielki, [w:] tenże, Poczet cesarzy bizantyjskich, Warszawa 1992, s. 117-182. 
wywodzić twierdzenie, że urodzenie Justyniana w okolicach Niszu wskazuje na jego słowiańskie korzenie. Opinie takie podtrzymywali m.in. historycy niemieccy Edward Gibbon (1737-1794) i Leopold von Ranke vel Rung (1795-1886) oraz historyk francuski Alfred Rambaud (1842-1905), a obalił je serbski historyk Nikola Radojčić, wykazując, że twierdzenia o słowiańskich korzeniach Justyniana, podobnie jak Aleksandra Wielkiego i św. Hieronima mogły mieć swe źródło w dziele chorwackiego historiografa Mavro Orbiniego Królestwo Stowian, a sam Alemanus głoszac taką tezę najprawdopodobniej opierał się na XVII-wiecznym falsyfikacie ${ }^{11}$.

Duchowa więź Słowian macedońskich z zajmowaną przestrzenią jako sferą wielkich własnych antenatów sprawiła, że do rodzimej tradycji asymilowano wszystkie postaci związane z dziejami ich ziem. Powrócono do pamięci o macedońskiej państwowości, jaką reprezentuje postać cara Samoila/Samuela (?-1014), twórcy silnego państwa obejmującego zachodnią Bułgarię, Serbię i Epir, z ośrodkiem w Macedonii (Ochryd). Kilkanaście dni po odsłonięciu pomnika Justyniana Wielkiego, po przeciwnej stronie Placu Macedonia, 28 czerwca 2011 r., odsłonięto powstały według projektu Dimitra Filipovskiego pomnik cara Samoila. I choć w tradycji bułgarskiej założone przez niego mocarstwo nosi nazwę Carstwa Zachodniobułgarskiego i uznawane jest za schyłkowy etap pierwszego państwa bułgarskiego, to Macedończycy nazywaja je Carstwem Samoila i uznaja je za pierwsze słowiańskie państwo macedońskie ${ }^{12}$. Jeszcze w XIX-wiecznych tekstach z obszaru bułgarsko-macedońskiego odwoływano się do niezwykłej odwagi tego władcy $^{13}$. Podpierając się autorytetem XVII-wiecznych historyków czy to Charlesa Dufresne du Cange, czy Mavro Orbiniego, nazywano go walecznym i dzielnym królem, który dzięki prowadzonym wojnom powiększył znacząco swoje państwo. Zapisane pieśni ludowe z połowy XIX w. gloryfikowały cara, często wymiennie z postacia Aleksandra Wielkiego. W folklorze ziem bułgarsko-macedońskich Samoil przeniesiony został w inne zupełnie czasy - przydano mu cechy wojownika, który walczył z Turkami. Ludowe losy postaci zdają się odzwierciedlać sytuację po kongresie berlińskim, kiedy utworzone zostało Księstwo Bułgarskie, a Macedonia nadal pozostawała pod władzą Imperium Osmańskiego. Młodemu pokoleniu Macedończyków nadano godność sławnych potomków cara, a on sam pozostawał ideałem waleczności dla gotowych do boju dzielnych następców. Jego związek z Ochrydem, gdzie sprawował władzę, na przełomie stuleci stawał się argumentem za włączeniem go do dziejów etnosu macedońskiego i uzasadniania

${ }^{11}$ Н. Радојчић, О тобожюем словенском пореклу иара Јустинијана, „Глас Српске краљевске академије. Други разред” 1940, t. CLXXXIV, 93, s. 169-248.

12 J. Rychlík, M. Kouba, Dějiny Makedonie, Praha 2003, s. 58, 313.

${ }_{13}$ Ǵorgija M. Pulevski (1828?-1895) - zwolennik odrębności macedońskiej, w swoim dziele historycznym, wykorzystując różne obce źródła historyczne opisał panowanie Samoila. Zob. Ѓ.М. Пулевски, Славјанско-маќедонска општа историја, подгот. Б. Ристовски, Б. Ристовска-Јосифовска, Скопје 2003, s. 23. 


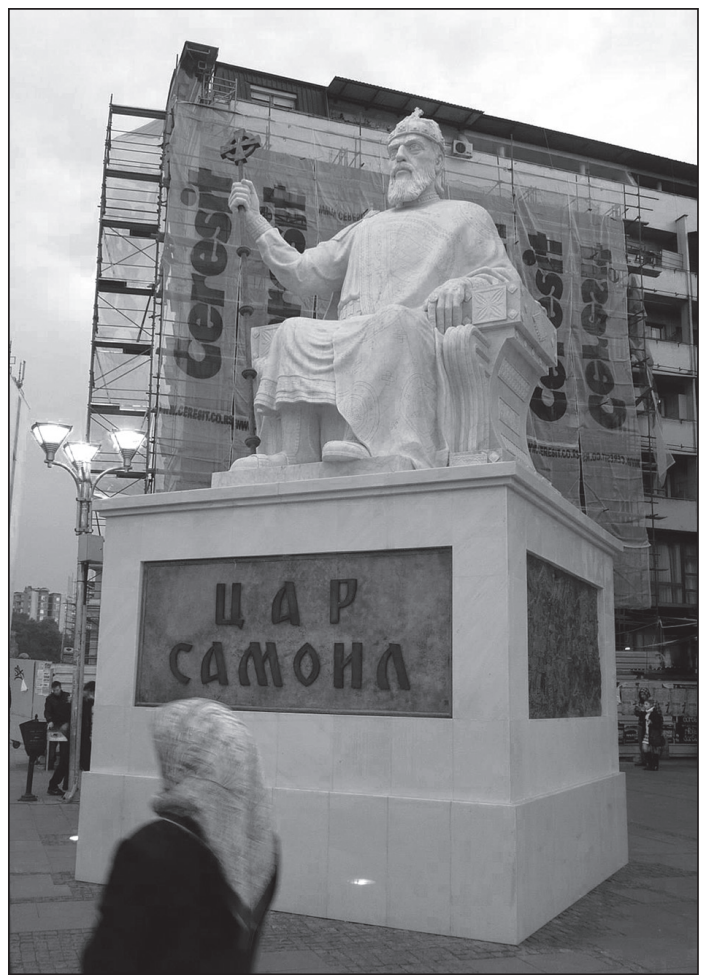

Zdjęcie 4. Pomnik cara Samoila, projekt: Dimitar Filipovski

kontinuum własnej państwowości. Odwołania do tego średniowiecznego władcy zachowały się w dokumentach politycznych, w których przywoływano go zwykle w kontekście walki o niezależne państwo czy to u boku Aleksandra Wielkiego, czy Cyryla i Metodego. Miało to służý słowiańskiej autoidentyfikacji i motywować starania o suwerenność Macedonii. Dla Macedończyków istotne stało się nie pochodzenie bohatera, ale topos ziemi ojczystej, co odzwierciedlały zarówno folklor, utwory literackie ${ }^{14}$, jak i dzieła muzyczne ${ }^{15}$. Odsłonięty w Skopje pomnik

${ }^{14}$ С. Антолјак, Самуиловата држава, Скопје 1968; Д. Наневски, Самуиловата крепост, [w:] Охридска поема, Скопје 1985; A. Popovski, List wiarołomny, wybór, wstep, tłum. M. Wawrzkiewicz, Warszawa 1998; P. Szirilow, Skała Samuiła, [w:] tenże, Anife i inne opowiadania, Warszawa 1972.

${ }_{15}$ Dla podkreślenia jego związków z Macedonią w byłej stolicy średniowiecznego państwa, Ochrydzie, wystawiano też operę Car Samuil (Цар Самyuл, 1965) autorstwa Kirila Makedonskiego. 
wzbudził wiele emocji poprzez dyskusję, jaką wywołał swą wypowiedzią burmistrz Ochrydu w październiku 2011 r. Stwierdził on, że jego miasto jest miejscem bardziej godnym uhonorowania cara Samoila i monument należałoby przenieść. W uzasadnieniu przekonywał, że Samoil bardziej związany jest z Ochrydem niż ze Skopje, gdyż stąd rządził państwem i tu wznoszą się mury jego twierdzy ${ }^{16}$.

Wokół pomnika Aleksandra Wielkiego, poza Justynianem Wielkim i carem Samoilem, znalazły się również postacie z dziejów nowożytnych - są to bohaterowie z okresu powstania z 1903 r., zwanego ilindeńskim, do którego odwołuje się preambuła konstytucji kraju. W maju 2011 r. odsłonięto monumenty bohaterów związanych z antyturecką walką Macedończyków. Pierwszy z nich, Goce Delčev (1872-1903), zajął w historii Macedonii poczesne miejsce ze względu na to, że jako bojownik o niezależne państwo cel ten sprecyzował. I choć zginął kilka miesięcy przed wybuchem powstania, znalazł się wśród jego najdzielniejszych bohaterów. Legenda o Delčevie tworzona była już za jego życia, początkowo na gruncie folkloru, później także literatury, publicystyki i historiografii. Literatura ludowa kreowała go na główną figurę walki antytureckiej, nadając mu znamiona typowe dla hajduka, a fantazja ludowego twórcy „uśmiercała” Delčeva na wiele różnych sposobów ('śmierć przez powieszenie, strzał prosto w serce) wzbogacając ten wizerunek swobodnie traktowanymi faktami z jego życia. Niezwykłą osobowość, spryt, odwagę i niezłomność przedstawiano w taki sposób, by stworzyć wzór bojownika o wyzwolenie pozostającym pod panowaniem osmańskim mieszkańcom ziem macedońskich. Życie Delčeva oraz jego przedwczesna śmierć uległy mitologizacji ${ }^{17}$. Obok jego pomnika stanął bliźniaczy niemal postument innego bohatera walk antytureckich Dame Grueva (1871-1906), który był bezpośrednim uczestnikiem walk w powstaniu 1903 r. Po klęsce zrywu wolnościowego Gruev nie ustawał w działaniach, które miały prowadzić do autonomii Macedonii ${ }^{18}$.

Chronologicznie traktując postacie, których pomniki zajęły centralny plac stolicy, kolejnym, odsłoniętym także w maju 2011 r. w ramach realizowanego projektu „Skopje 2014”, stał się przygotowany konceptualnie przez Miroslava Slavkovika monument Dimitrii Čupovskiego (1878-1940). Ten macedoński emigrant w Rosji, w pamięci historycznej Macedończyków pozostał niestrudzonym działaczem występującym $\mathrm{w}$ obronie statusu ludności macedońskiej wobec zagrożeń obcych państw ${ }^{19}$. Čupovski, jako założyciel Słowiańsko-Macedońskiego Towarzystwa Naukowo-Literackiego (Славјанско-македонско

$16 \mathrm{http} / / /$ www.time.mk/read/00d6747081/93e486e4f5/index.html (dostęp 3 III 2012).

17 Х. Андонов-Полјански, Гоце Делчев, t. 1-6, Скопје 1972; К. Христов, Гоце Делчев, София 1955; Н. Андонова, За Гоце Делчев войвода, София 1986; Гоце Делчев. Спомени, документи, материали, ред. Л. Панайотов, София 1978. Więcej о јеgo znaczeniu zob.: Leksykon tradycji bułgarskiej, red. G. Szwat-Gyłybowa, Warszawa 2011, s. 83-85.

18 С. Киселиновски, Македонски дејии (XX-ти век), Скопје 2002, s. 58-59.

19 Б. Ристовски, Македонскиот преродбенски XIX век, t. 1, knj. I, Скопје 2011, s. $123-124$. 
научно-литературно другарство), w latach 1913-1914 wydawał w Petersburgu pismo „Makedonskij gołos”, które stało się trybuną wolnościowej myśli Macedończyków. W publikowanych tu artykułach wskazywano na ich wkład w dziedzictwo cywilizacyjne Europy i pisano o ekspansjonistycznych dążeniach sasiednich państw wobec ziem, jakie zajmuja ${ }^{20}$. Niejednokrotnie też prezentowano cel Macedończyków, którym miało być samodzielne państwo i przy takich okazjach powoływano się na „silne argumenty polityczne”, za jakie uznawano wielkich macedońskich bohaterów. Odwoływano się więc zarówno do Aleksandra Wielkiego, św. Cyryla i Metodego, jak i do cara Samoila, jako postaci, które dokumentować miały znaczenie Macedonii w zamierzchłych czasach.

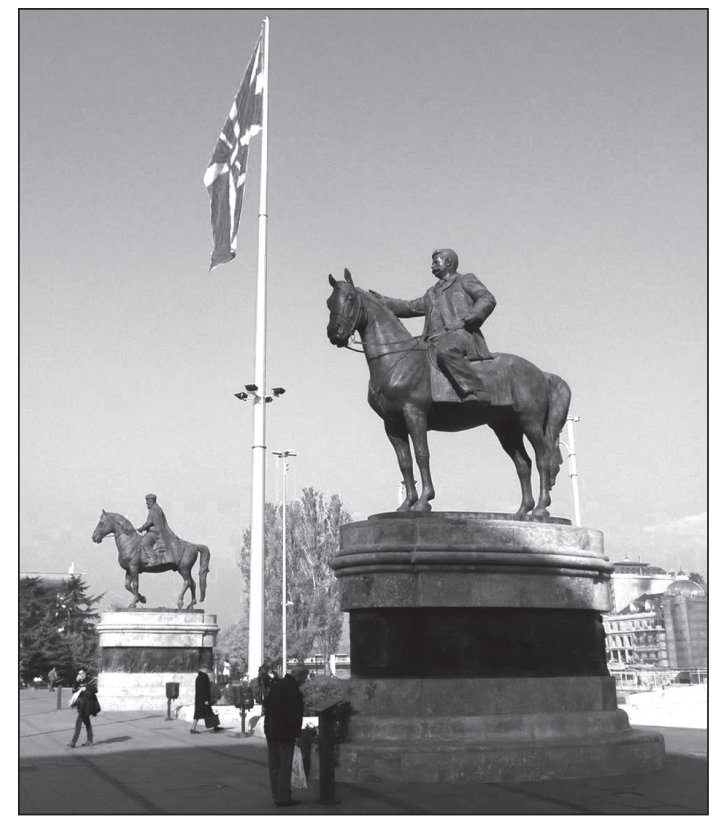

Zdjęcie 5. Pomnik Goce Delčeva i Dame Grueva, projekt: Žarko Bašeski

Poza uhonorowanymi poprzez pomniki bohaterami antyku, średniowiecza, okresu walk antytureckich i działaczami jawnie opowiadającymi się za niezależnością ziem macedońskich, w przestrzeni centralnego placu stolicy uczczono też postać, która przez dekady wymazana była z pamięci historycznej - po latach

${ }_{20}$ Б. Ристовски, Димитрија Чуповски (1878-1940) и Македонското научно-литературно другарство во Петроград, Скопје 1978, s. 180-189. 
oddano hołd Metodii Andonovowi Čento (1902-1957). Ten działacz polityczny był pierwszym przewodniczaccym Prezydium ASNOM, który opowiadał się za ideą zjednoczonej Macedonii i walczył o narodowe i ekonomiczne prawa dla Macedończyków. W następstwie konfliktu w łonie partii komunistycznej został skazany na 11 lat więzienia, a warunkowo wypuszczony na wolność, schorowany umarł wkrótce w osamotnieniu ${ }^{21}$. Przez czas istnienia Macedonii w strukturach federacyjnej Jugosławii przemilczany w rodzimej historiografii, został zrehabilitowany po rewizji wyroku z 1946 r. w wyniku starań syna dopiero w 1990 r.

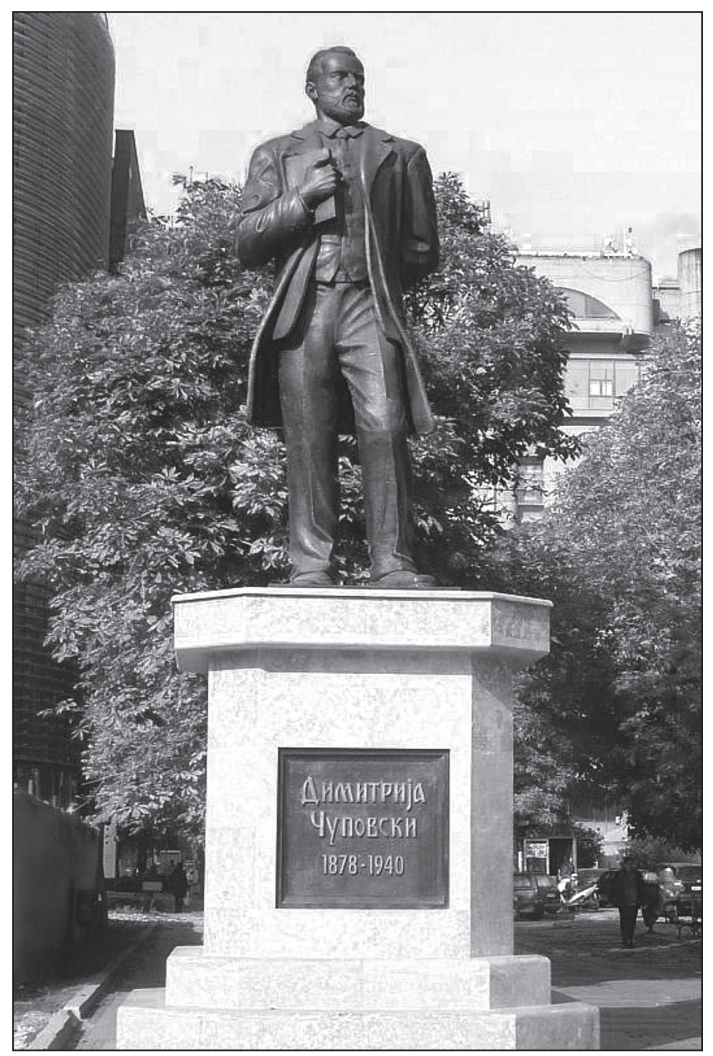

Zdjęcie 6. Pomnik Dimitrii Čupovskiego, projekt: Miroslav Slavkovik

${ }^{21}$ I. Stawowy-Kawka, Macedońskie idee wspólnotowe - Metodija Andonov Čento (1902-1957), [w:] Idee wspólnotowe Stowiańszczyzny, pod red. A.W. Mikołajczaka, W. Szulca, B. Zielińskiego, Poznań 2004, s. 171-182. 


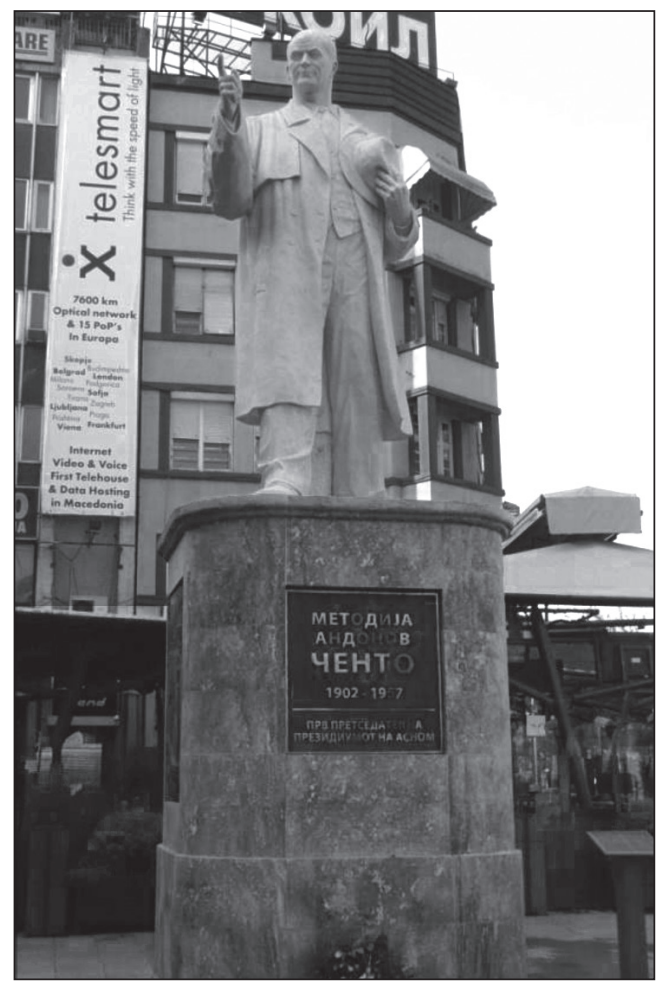

Zdjęcie 7. Pomnik Metodii Andonova Čento, projekt: Dimitar Filipovski

Przywracanie pamięci o przeszłości nie ogranicza się do Placu Macedonia, gdyż w jego bezpośrednim sassiedztwie, nad brzegiem rzeki Vardar, odsłonięto w lipcu 2010 r., również stanowiący część projektu „Skopje 2014”, pomnik Gemidžii, tajnej grupy macedońskich rewolucjonistów-anarchistów. Grupa młodych ludzi zasłynęła prowadzeniem akcji terrorystycznych wymierzonych w instytucje osmańskie oraz kapitał europejski. W założeniach jej członków miało to zwrócić uwagę wielkich mocarstw na ciagle nierozwiązaną kwestię macedońska. Najgłośniejszymi akcjami, jakie przeprowadzili zamachowcy, była seria ataków w Salonikach w okresie od 28 kwietnia do 1 maja 1903 r. - wysadzono wówczas w powietrze parostatek, pociag relacji Carigrad-Saloniki, Bank Otomański, sieć gazową oraz kawiarnie ${ }^{22}$.

${ }^{22}$ Działaności młodych zwolenników niepodległości Macedonii macedoński pisarz Jovan Boškovski poświęcił jedną ze swych powieści: Ј. Бошковски, Солунските атентатори, Скопје 1962. 
Panteon bohaterów związanych z różnymi okresami dziejów ziem macedońskich trafił także na drugi brzeg rzeki. Po tej stronie Vardaru stanął posag Ġorgija M. Pulevskiego (1828?-1895), zwolennika odrębności macedońskiej, autora słowników i monumentalnego dzieła Славјаннско-македонска општа ucmopuja. Autor zaprezentował w nim koncepcję etnogenezy Słowian, która stała się podstawową zakończoną u schyłku XIX stulecia, egzemplifikacją macedońskiej i słowiańskiej świadomości etnicznej, a także tożsamości regionalnej tego okresu. Słowiańsko-macedońska historia Pulevskiego włączona została do zbioru znaczacych dokumentów, które w jednoznaczny sposób dowodziły funkcjonowania idei wspólnoty słowiańskiej na Bałkanach z niepodważalnym w niej miejscem etnosu prawosławnej ludności, zamieszkującej przestrzeń macedońską - a wyrażającej się w idei „braterstwa Słowian”. Atrybutem wspólnoty, poza takimi samymi bądź zbliżonymi dziejami, był dla Pulevskiego język ogólnosłowiański, przyjęty jako element integrujący zbiorowość w sytuacji braku własnej państwowości ${ }^{23}$.

W niewielkiej odległości od monumentu Pulevskiego postawiono pomnik św. Cyryla (ok. 827-869) i św. Metodego (ok. 810-820-885), twórców pierwszego alfabetu słowiańskiego - głagolicy i świętych Kościoła powszechnego. Stworzony przez nich alfabet, jako pismo fonetyczne dostosowane do słowiańskiej gwary z okolic Salonik, stanowił cywilizacyjną innowację, która naruszyła monopol grecko-łacińskiego modelu $\mathrm{w}$ europejskiej kulturze piśmienniczej. W drugiej połowie XIX w., wraz z narastaniem nurtów separatystycznych na ziemiach macedońskich, ujawniała się tendencja do uznawania dziedzictwa Cyryla i Metodego za własne i włączania ich do rodzącej się wówczas wielkiej narracji własnego narodu. W dokumentach politycznych i pismach okolicznościowych, zwłaszcza po kongresie berlińskim, podkreślano słowiański i macedoński rodowód Cyryla i Metodego. Powoływano się na nich w dokumentach z przełomu wieków XIX i XX, a Słowiańsko-Macedońskie Towarzystwo Naukowo-Literackie w Petersburgu uczyniło ich swoimi patronami. W memorandum macedońskich emigrantów w Rosji, podpisanym po zakończeniu wojen bałkańskich, święci znaleźli się u boku innych „wielkich Macedończyków”, dowodząc rangi własnej tradycji narodowej. W czasach międzywojnia odwołania do nich zaczęły się pojawiać także w retoryce macedońskich działaczy komunistycznych, a podczas II wojny światowej w tekstach politycznych podnoszono temat ich „politycznej aneksji” przez „bułgarskich faszystów”. Po wojnie, kiedy Macedonia uzyskała autonomię w obrębie federacji jugosłowiańskiej, z manifestowaną obojętnością traktowano ich etniczną przynależność, a język słowiański, którym się posługiwali, nazywano staromacedońskim. W tym samym okresie św. Cyryl i Metody

${ }^{23}$ Zagadnienia te poruszałam w artykule: L. Moroz-Grzelak, Przenikanie kultur $i$ wizje tożsamości etnicznej w piśmiennictwie $\dot{G}$. Pulevskiego, „Z Polskich Studiów Slawistycznych” 2008, nr XL, seria II, s. 139-148. 
byli powszechnie wybierani na patronów macedońskich szkół i placówek naukowych, ale określenie „święci” w nazwach patronackich przywrócono im dopiero po upadku Jugosławii.

Dotychczas po drugiej stronie rzeki Vardar znalazły się jeszcze dwa pomniki. Jeden z nich, na wspólnym cokole, przedstawia postać św. Klimenta Ochrydzkiego (lata 30. IX w. - 916) i św. Nauma Ochrydzkiego (830-910), przyjętych w tradycji za najbardziej utalentowanych uczniów Cyryla i Metodego. Kliment, uznawany za założyciela tzw. ochrydzkiej szkoły piśmienniczej, za pierwszego biskupa języka słowiańskiego i tłumacza ksiag cerkiewnych z greki, stał się patronem macedońskiej Cerkwi autekefalicznej i pozostał „fundamentem" tradycji narodowej, z którą związany jest także św. Naum - jeden z twórców literatury cerkiewnej i założyciel monasteru nad Jeziorem Ochrydzkim.

Ostatnim, na razie, stojącym po tej stronie Vardaru pomnikiem, który stanowi realizację projektu „Skopje 2014”, odsłoniętym w roku obchodów 20. rocznicy niepodległości państwa (w lutym 2011 r.), jest pomnik dowódcy powstania antytureckiego Karpoša - hajduka z wieku XVII, który stracony został za wzniecenie buntu w $1689 \mathrm{r}$.

Pomnikowa pamięć o wielkich bohaterach ziem macedońskich nie ogranicza się jedynie do postaci przedstawionych na placu i w jego bezpośrednim sasiedztwie. W ramach realizowanego projektu „Skopje 2014” odsłonięto 6 stycznia 2012 r. łuk triumfalny, który stał się artystycznym konceptem przedstawiającym całość macedońskiej historii.

Na płaskorzeźbach umieszczonych na jego ścianach znalazły odzwierciedlenie sceny z prehistorii ziem macedońskich: tzw. zalivot na koskite stanowiący ślady osad z okresu neolitu odnalezione na dnie Jeziora Ochrydzkiego, obrazy odnoszące się do antyku z postacią Aleksandra Wielkiego, a także do czasów średniowiecza ze św. Cyrylem i Metodym, św. Klimentem i św. Naumem oraz carem Samoilem i legendarnym królewiczem Marko. Nie zabrakło też przywódcy powstania antytureckiego Karpoša. Wiek XX obrazują reliefy odnoszace się do Ilindenu, ASNOM, exodusu Słowian z Macedonii Egejskiej aż po proklamację niepodległości w $1991 \mathrm{r}$.

Macedońska pamięć historyczna, wpisując się w projekt urbanistyczny stolicy państwa, nie ogranicza się jedynie do realizowanego planu, w ramach którego oddany zostanie kolejny pomnik-fontanna, tym razem ukazujący Filipa II. W tej sytuacji wydaje się, że nie ma znaczenia fakt, że jeszcze w listopadzie 2011 r. w innej części miasta odsłonięto również pomnikowy kompleks - fontannę poświęconą Filipowi II, a wymienieni wcześniej bohaterowie mają swoje monumenty w innych częściach miasta. Odnosi się to do pomników Klimenta Ochrydzkiego, którego wcześniejszy posąg, zlokalizowany w pobliżu cerkwi katedralnej jego imienia, odsłonięto w 2010 r. czy statui Cyryla i Metodego, którzy jako patroni uniwersytetu w Skopje mają na terenie uczelni dwie pomnikowe 
realizacje. Jedna, autorstwa Boro Mitrikeskiego z 1990 r., druga natomiast, wykonana według projektu Tome Serafimovskiego ${ }^{24}$, z 2005 r. stojąca w auli uniwersyteckiego rektoratu. Także Goce Delčev miał już swoją wcześniejsza rzeźbę, usytuowaną w parku miejskim Skopje. Dzieło autorstwa wywodzącego się z Macedonii Egejskiej rzeźbiarza Ljubomira Dalčeva, jako dar Bułgarów dla narodu macedońskiego, odsłonięto w 1966 r. Przestrzeń miejską zdobią też kolejne figury postaci nierozerwalnie związanych $\mathrm{z}$ historią powstania ilindenskiego: Nikoli Kareva (1877-1905), który pełnił funkcję przewodniczącego władz powołanej w trakcie tego zrywu Republiki Kruszewskiej, oraz innego uczestnika walk antytureckich Jane Sandanskiego (1872-1915).

Swoich pomników w ostatnim okresie doczekali się również macedońscy pisarze, myśliciele związani z najnowszymi dziejami narodu i państwa. Drugim monumentem upamiętniono w Skopje Krste Misirkova (1874-1926), uznanego za „ojca narodu macedońskiego" ${ }^{25}$. Przeszedł on do historii jako filolog i autor cyklu artykułów opublikowanych pod tytułem За македонцките работи, w których dokonał analizy sytuacji ziem macedońskich i opowiedział się za utworzeniem niezależnego państwa. Pamięć macedońska uczciła też Blaže Koneskiego (1921-1993), jednego z kodyfikatorów współczesnego języka macedońskiego, odsłaniając przed gmachem Macedońskiej Akademii Nauk i Sztuk w grudniu 2011 r. poświęcony mu monument, a także Slavko Janevskiego (1920-2000), autora pierwszej napisanej w języku macedońskim powieści, czy urodzonej w Skopje Matki Teresy z Kalkuty (1910-1997) i arcybiskupa Dositeja (1906-1981), który przeszedł do historii jako pierwszy zwierzchnik Macedońskiej Cerkwi Prawosławnej.

Przegląd dzieł pomnikowych, ukazujących wielkich bohaterów związanych z przeszłością ziem macedońskich, wskazuje na kształt współczesnej pamięci historycznej, która - opierając się na zasadzie primordialności - włącza do swego dziedzictwa postacie związane z zajmowaną przestrzenia. Macedonia zdaje się nadrabiać proces, jaki w innych państwach Europy przebiegał wcześniej. Za przykład pomnikowego sposobu kultywowania historii i podkreślania znaczenia swego państwa mogą posłużyć nie tylko łuki triumfalne, jakie stanęły w Paryżu, Bukareszcie, Rzymie czy Budapeszcie, ale też wielkie pomniki ku czci bohaterów przyjmowanych do własnej historii. Znamienny przypadek odnajdujemy choćby w niemieckiej pamięci historycznej. Kilka lat po wojnie francusko-pruskiej,

${ }^{24}$ Rzeźbiarz Tome Serafimovski jest autorem większości odsłanianych w Macedonii monumentów. Według jego projektów powstały pomniki Matki Teresy z Kalkuty (1998 r.), Klimenta Ochrydzkiego (Ochryd 2006 r., Skopje 2010 r.), Krste Misirkova (2011 r.), arcybiskupa Dositeja (2007 r.), Slavko Janevskiego (2010 r.).

25 „Таткото на македонската нација - tak określają Misirkova uczeni macedońscy, a wśród nich badacz literatury i poeta Gane Todorovski - zob. В. Цветаноски, Враќањето на Мисирков, но не оној што го знаеме, „У трински весник” 2008, br. 2670. 
w 1875 r. w teutoburskim lesie w pobliżu miasta Detmold stanął ogromnych rozmiarów pomnik znanego z walk z Rzymianami Arminiusa (18/17 BC - AD 21).

Przedstawiany jako wyzwoliciel Germanów, zyskał on cechy bohatera chrześcijańskiego w XVI stuleciu, a w XIX w., w okresie scalania Niemiec, stał się symbolem Niemca. Macedonia w takim kontekście stanowi przykład państwa współczesnej Europy, które przyjęło opóźnioną o kilka dziesiątków lat rolę depozytariusza dziedzictwa wydzielonej przestrzeni, z jej wielkimi bohaterami. Pamięć o wiekach minionych i postaciach, które na trwałe weszły do historii, stała się istotnym czynnikiem prowadzącym do scalania wspólnoty państwowej, wskazując i dokumentując nie tylko własny wkład w rozwój cywilizacji europejskiej i uzasadniając swoje istnienie, ale także rangę tej historii w obliczu sporów z Grecją czy obawami przed albańskimi zakusami na swe terytoria. 